\title{
IN VITRO AND IN VIVO EVALUATION OF FLOATING GASTRORETENTIVE DRUG DELIVERY SYSTEM OF CIMETIDINE USING HARD ALGINATE CAPSULES
}

\author{
RIRIYEN DESSY N SIAHAAN, HAKIM BANGUN*, SUMAIYAH
}

Department of Pharmaceutical Technology, Faculty of Pharmacy, Nanomedicine Centre, University of Sumatera Utara, Jl. Tri Dharma No. 5, Kampus USU, Medan, Indonesia. Email: hakimb17@yahoo.com

Received: 25 July 2017, Revised and Accepted: 21 February 2018

\section{ABSTRACT}

Objective: The objective of this study was to evaluate in vitro and in vivo of gastroretentive drug delivery system of cimetidine using hard alginate capsules.

Methods: Drug release study was tested to various hard alginate capsules containing 200 mg cimetidine with paddle method dissolution apparatus in artificial gastric fluid $\mathrm{pH}$ 1.2. Concentrations of cimetidine were measured using ultraviolet spectrophotometer at $218.4 \mathrm{~nm}$ wavelength. The product that fulfilled the sustained release profile was evaluated for bioavailability using male rabbits at dose $9.3 \mathrm{mg} / \mathrm{kg}$ orally, and the antiulcer studies were evaluated by $\mathrm{HCl}$-induced ulcer method at cimetidine dose $18 \mathrm{mg} / \mathrm{kg}$ once a day orally. Gastric lesions were evaluated by macroscopic and microscopic observations.

Results: The results of drug release test showed that hard alginate capsule made from sodium alginate 500-600 cP gave sustained release profile of cimetidine for $12 \mathrm{~h}$. In vivo bioavailability studies showed that cimetidine given with hard alginate capsules gave higher of $\mathrm{Cmax}$, Tmax, and area under the curve of cimetidine compared to cimetidine that given with conventional hard gelatin capsules. The antiulcer studies showed that the healing effect of cimetidine that given with hard alginate capsules was faster than cimetidine given in suspension form. Cimetidine that given with hard alginate capsules macroscopically showed no gastric lesion and histopathologically also showed normal gastric mucosa of rats after 4 days treatment. However, cimetidine given in suspension form showed of $0.036 \pm 0.024$ ulcer index and microscopically there was still erosion of gastric mucosa of rats after 4 days treatment.

Conclusion: Floating gastroretentive of cimetidine using hard alginate capsules give a sustained release of cimetidine with better bioavailability and antiulcer effect of cimetidine.

Keywords: Hard alginate capsules, Gastroretentive, Cimetidine, Release, Bioavailability, Antiulcer effect.

(C) 2018 The Authors. Published by Innovare Academic Sciences Pvt Ltd. This is an open access article under the CC BY license (http://creativecommons. org/licenses/by/4. 0/) DOI: http://dx.doi.org/10.22159/ajpcr.2018.v11i6.24731

\section{INTRODUCTION}

Peptic ulcer is erosion at anywhere on mucosal lining in the gastrointestinal tract, usually in the stomach or duodenum. The two main causes of ulcers are too little mucus production or excessive acid production in the stomach [1]. Oral drug delivery routes are the most convenient and most commonly used as route of administration [2]. However, this route has several physiological problems including gastric retention time and unexpected levels of gastric emptying. This situation drastically reduces the drug absorption time, which is followed by reduced bioavailability [3]. These limitations have prompted to design gastroretentive drug delivery systems that can retain in the stomach for extended time and also increase the bioavailability of the drug by increasing gastric retention time.

Several approaches of dosage formulations with gastroretentive system have been developed to achieve controlled release of cimetidine to stay longer in the stomach [4-6]. One of the gastroretentive systems is floating system [7]. Recently, it was reported that the formulation floating tablets of nizatidine using hydroxypropyl methylcellulose (HPMC K4M) [8], design and optimization of multiparticulate gastroretentive delivery system of ranitidine hydrochloride [9], and formulation and evaluation of ranitidine hydrochloride as floating in situ gel [10].

Sodium alginate is a polysaccharide that is derived from seaweed (brown algae) and non-toxic [11]. Alginate can be used for the preparation of periodental drug delivery system and gastroretentive drug delivery system of ranitidine $\mathrm{HCl}$ and antacids [12-16].
Alginate interacts with organic diacidic base piperazine [17] and calcium salts. It is well known that interaction of alginate with calcium salts solution form gel immediately. Based on the interaction properties of alginate and calcium ion, Bangun et al. reported the preparation and characterization of hard alginate capsules shell and it is found that hard alginate capsules shell is resistant or do not disintegrate in simulated gastric fluid $\mathrm{pH}$ 1.2, but it swells and disintegrates in simulated intestinal fluid [18]. Previously, it was studied the floating gastroretentive of amoxicillin using hard alginate capsules and its antibacterial activities of amoxicillin [19].

Cimetidine is a class of $\mathrm{H}_{2}$ receptor antagonists used to treat gastric ulcers and duodenal ulcers, gastroesophageal reflux disease, and gastric ulcers due to NSAIDs. Cimetidine has a half-life of $2 \mathrm{~h}$. It is poorly absorbed from the lower gastrointestinal tract, and the bioavailability of cimetidine is $<70 \%$ [20]. Therefore, it is necessary to raise the bioavailability and enhances the antiulcer effect of cimetidine.

In this paper, it will be discussed the application of hard alginate capsules as floating drug delivery system of cimetidine. The lag time, floating time, drug release, bioavailability, and antiulcer effect will be discussed

\section{MATERIALS AND METHODS}

Materials

Cimetidine was obtained from Jiangsu Baosheng Longcheng Pharmaceutical Co., Ltd., China. Hydrochloric acid, acetonitrile, 
perchloric acid, formaldehyde, ethanol, xylene, hematoxylin, and eosin, all were the products of Merck. Sodium alginate 80-120 cP, sodium alginate $300-400 \mathrm{cP}$, and sodium alginate 500-600 cP were purchased from Wako Pure Chemical Industries, Ltd., Japan. Hard alginate capsules (size 1 used for in vitro study and capsules with length $0.9 \mathrm{~mm}$ and diameter $0.2 \mathrm{~mm}$ used for vivo study) were obtained from Laboratory of Physical Pharmacy, Faculty of Pharmacy, University of Sumatera Utara. Hard gelatin capsules obtained from A to H Pharmacy, Medan. The photo of capsules is shown in Fig. 1.

\section{Animals}

Healthy male rabbits with weight $1.8-2 \mathrm{~kg}$ for bioavailability studies were used. Rattus norvegicus rats used weighing 180-200 g for antiulcer studies were maintained in standard animal house, given standard pellet diets and tap water ad libitum. The rabbits and rats were fasted from all medications at least 2 weeks before the tests were done. All the rats and rabbits were adhered to the standard operating procedures and approved by the Animal Research Ethics Committee in Faculty of Mathematics and Natural Sciences University of Sumatera Utara, before the beginning of the project work.

\section{Methods}

\section{Floating lag time and floating time}

Hard alginate capsules made from sodium alginate 500-600 cP were placed in simulated gastric fluid pH 1.2 at $500 \mathrm{ml}$ flask, and both the time needed to float on the surface of the fluid and the floating time were determined as conducted in previous experiment [19].

\section{In vitro drug release studies}

The drug release from hard alginate capsules made from sodium alginate 500-600 cP was performed using paddle method with $100 \mathrm{rpm}$ speed in simulated gastric fluid ( $\mathrm{pH} 1.2)$ at $37 \pm 0.5^{\circ} \mathrm{C}$. The capsules contained 200 mg cimetidine. Drug released amount was determined using ultraviolet (UV) spectrophotometer at wavelength $218.4 \mathrm{~nm}(\mathrm{n}=3)$.

\section{In vivo studies}

Bioavailability studies

The test was done by cross-over design method using six rabbits which washout period was 2 weeks [21]. Cross-over design of cimetidine administration into rabbits can be shown in Table 1.

In bioavailability studies, the dose of cimetidine given was determined from the conversion of human dose (cimetidine $200 \mathrm{mg}$ ) to rabbit dose. The cimetidine dose used for rabbits was $9.3 \mathrm{mg} / \mathrm{kg}$. Water was given ad libitum during fasting and $2 \mathrm{ml}$ every $1 \mathrm{~h}$ throughout the experiment. Determination of absorption curve, calibration curve, and drug concentrations following the method reported by Mastiholimath [22,23], as follows

\section{Determination of absorption curve}

The absorption curve was prepared by preparing a solution of cimetidine in acetonitrile at concentration of $6 \mu \mathrm{g} / \mathrm{ml} .1 \mathrm{~mm}$ of the solution was added to $5 \mathrm{ml}$ using acetonitrile, added $1 \mathrm{ml}$ of rabbit blood plasma containing no drug, centrifuged at $2500 \mathrm{rpm}$ for $15 \mathrm{~min}$. $4 \mathrm{ml}$ of the supernatant was piped out to a flask which contained $0.2 \mathrm{ml}$ of $1.47 \mathrm{M}$ perchloric acid. The absorption was measured at 200-400 nm wavelength. The blank was prepared using plasma of undosed rat as conducted in the plasma of dosed rat.

\section{Determination of calibration curve}

The calibration curve preparation of cimetidine as follows. Cimetidine solutions in acetonitrile were prepared at concentrations of $2,4,6,8$, and $10 \mu \mathrm{g} / \mathrm{ml}$. $1 \mathrm{ml}$ of this solution was made up to $5 \mathrm{ml}$ acetonitrile. To each of these solutions, $1 \mathrm{ml}$ of undosed rabbit blood was added and the contents centrifuged at $2500 \mathrm{rpm}$ for $15 \mathrm{~min} .4 \mathrm{ml}$ of supernatant was piped out and into flask which contained $0.2 \mathrm{ml}$ of $1.47 \mathrm{M}$ perchloric acid, and the absorbance was measured at wavelength $265.60 \mathrm{~nm}$. The blank was prepared using plasma from the undosed animal.
Determination of drug concentrations

Blood samples, each $2 \mathrm{ml}$, were collected from the marginal ear vein of the rabbits and transferred into heparinized centrifuge tubes just before dosing (undosed sample), then rabbits are given cimetidine according to cross-over design method that has been explained above, and the intervals of blood sampling were $15,30,60,90,120,180,240$, $360,400,440,480,600$, and $720 \mathrm{~min}$. Blood samples were centrifuged at $1500 \mathrm{rpm}$ for $15 \mathrm{~min}$ and the plasma was separated. One undosed plasma sample was prepared as blank. $5 \mathrm{mms}$ of acetonitrile was added into each $1 \mathrm{ml}$ of other plasma samples. The tubes were centrifuged at $2500 \mathrm{rpm}$ for $15 \mathrm{~min}, 4 \mathrm{ml}$ of the supernatant was piped out and put into flask which contained $0.2 \mathrm{ml}$ of $1.47 \mathrm{M}$ perchloric acid, and the drug concentrations were determined by UV spectrophotometer at $265.60 \mathrm{~nm}$ wavelength.

\section{Antiulcer studies}

Antiulcer studies were conducted in healthy white male rats with weight 150-200 g. For antiulcer activity experiment, the dose of drugs given was determined from the conversion of human dose (cimetidine $200 \mathrm{mg}$ ) to rat dose. The cimetidine dose used for rats was $18 \mathrm{mg} / \mathrm{kg}$.

The antiulcer activity was studied following the method previously reported [23]. 42 rats were fasted for $36 \mathrm{~h}$ before the test, then all of rats were orally induced with $1 \mathrm{ml}$ of $0.6 \mathrm{~N} \mathrm{HCl}$ solution to produce gastric lesions. After $1 \mathrm{~h}$, six rats were sacrificed by chloroform inhalation and the stomachs were observed to determine the condition of gastric lesions. This condition was thought as initial condition of gastric lesion. The remaining rats (36 rats) were divided into three groups and each group divided two subgroups, each subgroup consisted of six rats.

Group I (negative control): Given with $1 \mathrm{ml}$ distilled water orally once a day for 4 days. Six rats were sacrificed after 2 days treatment and another six rats were sacrificed after 4 days treatment.

Table 1: Cross-over design of cimetidine administration into rabbits

\begin{tabular}{lllll}
\hline Rabbits & $\begin{array}{l}\text { Dosage } \\
\text { form }\end{array}$ & $\begin{array}{l}\text { Washout } \\
\text { for 2 weeks }\end{array}$ & Rabbits & $\begin{array}{l}\text { Dosage } \\
\text { form }\end{array}$ \\
\hline 1 & $\mathrm{~A}$ & & 1 & $\mathrm{~B}$ \\
2 & $\mathrm{~A}$ & 2 & $\mathrm{~B}$ \\
3 & $\mathrm{~A}$ & 3 & $\mathrm{~B}$ \\
4 & $\mathrm{~B}$ & 4 & $\mathrm{~A}$ \\
5 & $\mathrm{~B}$ & 5 & $\mathrm{~A}$ \\
6 & $\mathrm{~B}$ & 6 & $\mathrm{~A}$ \\
\hline
\end{tabular}

A: Gelatin capsules containing cimetidine $(9.3 \mathrm{mg} / \mathrm{kg})$, B: Hard alginate capsule made from sodium alginate $500-600 \mathrm{cP}$ containing cimetidine $(9.3 \mathrm{mg} / \mathrm{kg})$
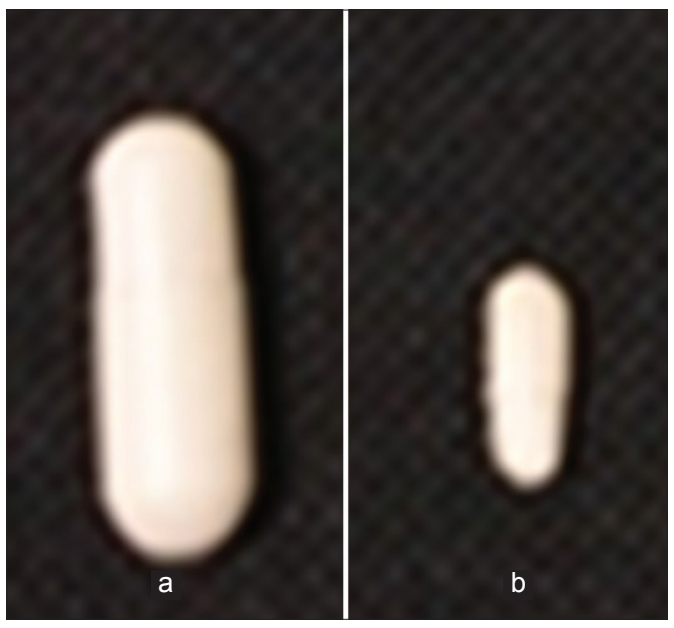

Fig. 1: Hard alginate capsules used for in vitro studies (a) and for in vivo studies (b) 
Group II (positive control): Given with $1 \mathrm{ml}$ cimetidine suspension $(18 \mathrm{mg} / \mathrm{kg})$ once a day for 4 days. Six rats were sacrificed after 2 days treatment and another six rats were sacrificed after 4 days treatment.

Group III (test group): Given with one hard alginate capsule made from sodium alginate $500-600 \mathrm{cP}$ containing cimetidine orally $(18 \mathrm{mg} / \mathrm{kg})$ once a day for 4 days. The rats were given $2 \mathrm{ml}$ distilled water every $1 \mathrm{~h}$ [24]. Six rats were sacrificed after 2 days treatment and another six rats were sacrificed after 4 days treatment.

For macroscopic observation, the number of gastric lesion and the area of lesion were determined. The lesion index was counted by area of mucosal damage $\left(\mathrm{mm}^{2}\right)$ divided by area of gastric mucosa $\left(\mathrm{mm}^{2}\right)[25,26]$. The length and width of each lesion in $\mathrm{mm}$ were measured with a micrometer. For microscopic observation, the stomachs were washed with $0.9 \% \mathrm{NaCl}$ solution and immersed in $10 \%$ formalin solution, then processed for histological staining with hematoxylin-eosin.

\section{RESULTS AND DISCUSSION}

\section{Floating capability}

Floating lag time of all hard alginate capsules containing cimetidine was $0 \mathrm{~min}$, it means that when capsule was immersed in simulated gastric fluid $\mathrm{pH} 1.2$, it floated immediately as found in the previous experiment [19]. The capsule floated during drug release experiment for $12 \mathrm{~h}$ as shown in Fig. 2. Capsule floated was due to the air was entrapped inside of the capsule shell and the density of alginate capsule shell was lower than the density of simulated gastric fluid.

\section{In vitro drug release studies}

Hard alginate capsules which were placed in artificial gastric fluid (pH 1.2) remained in intact condition during drug release. This is caused by the content of alginate capsules $47.5 \%$ is calcium guluronate that is insoluble in simulated gastric fluid $(\mathrm{pH}$ 1.2) [27]. Therefore, hard alginate capsules can be used as floating gastroretentive drug delivery system. Hard alginate capsules disintegrate in the small intestine.

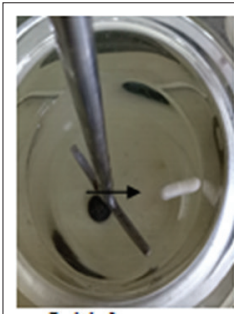

Initial

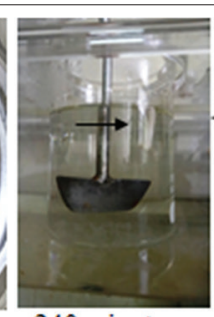

240 minutes

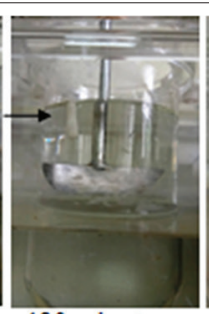

480 minutes

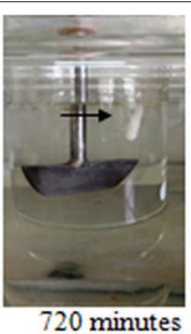

720 minutes
Fig. 2: Floating of hard alginate capsule containing cimetidine during drug release experiment in artificial gastric fluid at $37^{\circ} \mathrm{C}$. Arrow shows the floating capsule
The difference of cimetidine release from hard gelatin capsules and various types of alginate capsules is shown in Fig. 3. The release of cimetidine from hard gelatin capsule is an immediate release which drug released $81.6 \%$ at $5 \mathrm{~min}$, while the release of cimetidine from hard alginate capsule is a non-immediate release. The release of cimetidine from hard alginate capsules is slower with higher viscosity of sodium alginate used to prepare the hard alginate capsules. This is due to differences in the characteristics of the three types of alginate capsule, especially in terms of thickness. The hard alginate capsule made from sodium alginate $500-600 \mathrm{cP}$ is thicker than the hard alginate capsule made from sodium alginate $80-120 \mathrm{cP}$ and $300-400 \mathrm{cP}$, so the release of cimetidine from hard alginate capsule is slower. As a sustained release product, the release of cimetidine from hard alginate capsules made from sodium alginate $80-120 \mathrm{cP}$ and $300-400 \mathrm{cP}$ is too fast and does not meet the general requirement of sustained release product, while the cimetidine release from alginate hard alginate made from sodium alginate $500-600 \mathrm{cP}$ is slower as shown in Fig. 3.

The cimetidine release from alginate capsules made from sodium alginate $500-600 \mathrm{cP}$ at $180 \mathrm{~min}$ was $49.80 \%$, at $360 \mathrm{~min}$ was $61.31 \%$ and at $720 \mathrm{~min}$ is $80.03 \%$. This release profile meets the general sustained release requirements [28], as shown in Table 2. Therefore, hard alginate capsules made from sodium alginate 500$600 \mathrm{cP}$ provide optimal drug release as a gastroretentive floating drug delivery system in an artificial gastric medium of $\mathrm{pH}$ 1.2. In previous study, about floating gastroretentive of amoxicillin using hard alginate capsules, to obtain the sustained release profile of amoxicillin from hard alginate capsules, the amoxicillin should be the solid dispersion form [19]. However, in this study, to obtain the sustain release profile of cimetidine using hard alginate capsules does not need to change the cimetidine to solid dispersion form of cimetidine. To obtain the sustained release of cimetidine simply to select the alginate capsules type, i.e., alginate capsules made from sodium alginate $500-600 \mathrm{cP}$

\section{In vivo studies}

\section{Bioavailability studies}

The plasma of cimetidine levels obtained in this study is shown in Fig. 4. The mean pharmacokinetic parameters of drug from hard gelatin capsule and hard alginate capsules made from sodium alginate 500$600 \mathrm{cP}$ are listed in Table 3.

The pharmacokinetics parameters for bioavailability are Cmax, Tmax, and area under the curve (AUC). Cmax representing the maximum plasma drug concentration obtained after oral administration of drug [21]. The difference in Cmax values can be seen in Fig. 4 and Table 4. The Cmax values obtained on using hard gelatin capsules and hard alginate capsules were $4.429 \pm 1.512$ and $6.674 \pm 2.629 \mu \mathrm{g} / \mathrm{ml}$, respectively. It is shown that the Cmax is higher in using hard alginate capsules than hard gelatin capsules, but it is not different statistically significant ( $p>0.05$ ).

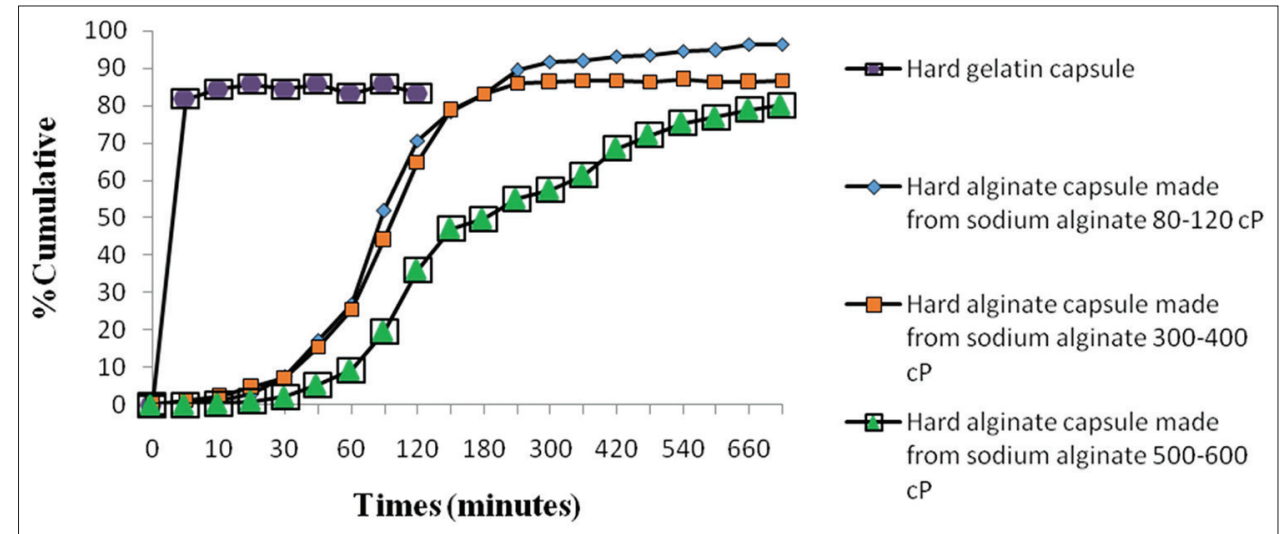

Fig. 3: Graph of cimetidine release from hard alginate capsules and gelatin capsules in artificial gastric fluid $\mathrm{pH} 1.2$ at $37^{\circ} \mathrm{C}$ 
Tmax representing the time required to reach maximum drug concentration after oral administration of drug [21]. The Tmax values obtained on using hard gelatin capsules and hard alginate capsules were 15 and $180 \mathrm{~min}$, respectively. It is shown that the Tmax is longer in using hard alginate capsules and this value is significant difference. It is caused by drug release from hard alginate, capsules are a sustained release, while from hard gelatin capsules are immediate release.

AUC representing the total amount of active drug that reaches the systemic circulation [21]. The difference in AUC values can be seen in Table 3. The AUC values obtained on using hard gelatin capsules and hard alginate capsules were $2290.315 \pm 475.162$ and 3141.055 $\pm 835.113 \mathrm{~min} . \mu \mathrm{g} / \mathrm{ml}$, respectively. It shows that the AUC is larger in using hard alginate capsules than using hard gelatin capsules, but it is not different statistically significant $(\mathrm{p}>0.05)$

Furthermore, the correlation of drug dissolved in vitro with drug absorbed in vivo is shown in Fig. 5 . The correlation $\left(\mathrm{R}^{2}\right)$ of in vitro cimetidine released in simulated gastric fluid $\mathrm{pH} 1.2$ with in vivo cimetidine absorbed is 0.957 . It shows that it is a good correlation between in vitro and in vivo results.

\section{Antiulcer studies}

Macroscopically and microscopically of normal rats gastric mucosa The stomach wall comprises four concentric layers: Mucosa, submucosa, muscularis externa, and serosa. The mucosa of the fundic stomach is composed of the usual three components: (1) An epithelium lining the lumen; (2) an underlying lining connective tissue, the lamina propria; and (3) the smooth muscle layers forming the muscularis mucosa [29]. Fig. 6 shows rat normal gastric mucosa (a), and microscopic of gastric mucosa (b) that was observed in this experiment.

Macroscopic and microscopic of gastric mucosa after induction with 0.6 $\mathrm{N} \mathrm{HCl}$ solution

After orally induction with $1 \mathrm{ml} 0.6 \mathrm{~N} \mathrm{HCl}$ solution, all rats (Group I) showed gastric lesions as shown in Fig. 7. The lesions were on the surface of the gastric mucosa. The lesion of gastric mucosa was due to gastric mucosa was exposed directly with $0.6 \mathrm{~N} \mathrm{HCl}$ solution. Hydrochloric acid is an acid that can cause the mucosal blood flow to be damaged in large quantities. The lesion index was $0.44 \pm 0.08$ and the number of gastric lesion was $8.16 \pm 2.22$ as shown in Table 3. Fig. 7

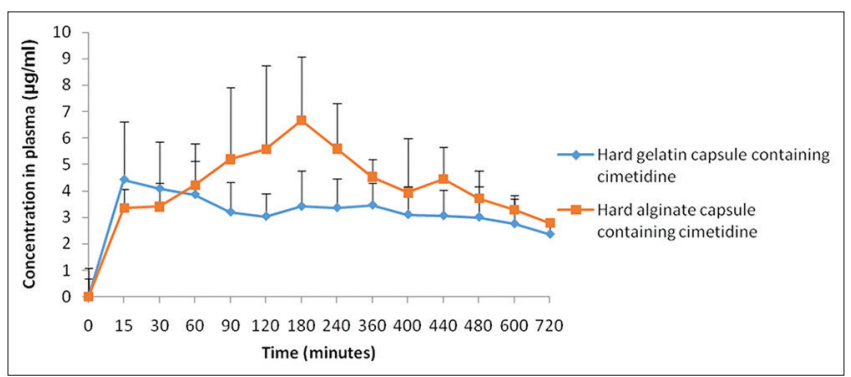

Fig. 4: Plasma cimetidine concentrations in rabbits blood plasma $(n=6)$

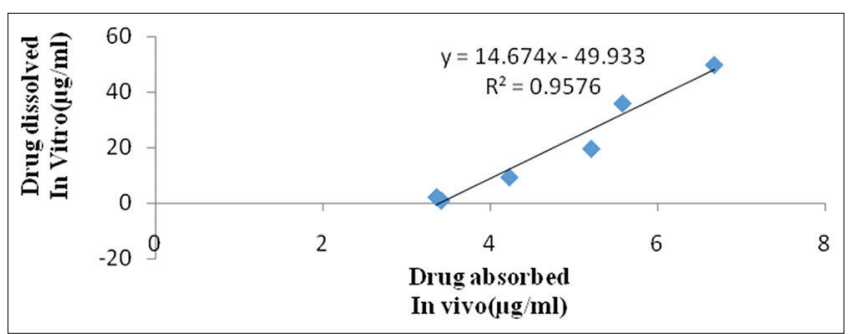

Fig. 5: The correlation of in vitro cimetidine released with in vivo cimetidine absorbed using hard alginate capsules shows there were lesions in the stomach rats induced by $\mathrm{HCl} 0.6 \mathrm{~N} 1 \mathrm{~h}$ before surgery. Fig. 8 shows microscopic of stomach tissue after $\mathrm{HCl} 0.6$ $\mathrm{N}$ administration. It shows many lesions in stomach of all rats.

Without treatment

Two days: The condition of rats' gastric mucosa of Group II (without treatment) is shown in Fig. 9. After 2 days, there were still many lesions in gastric mucosa. The lesion index was $0.18 \pm 0.16$ and the number of lesion was 5.8 \pm 2.92 . If we compared with initial condition, after 2 days, the lesion index and number of lesion are reduced but it is not different significantly. Fig. 10 shows the microscopic of gastric mucosa of rats after 2 days treatment. It shows there are many erosions in the stomach of all rats tested.

Four days: Fig. 11 shows the gastric mucosa of rats after 4 days without treatment. It shows that there are still many of lesions of stomach. After 4 days, the lesion index was $0.09 \pm 0.05$ and the number of lesion was $5 \pm 3.52$. If we compared with the condition at 2 days, after 4 days, the lesion index and number of lesion were also decreased, but statistically, it is not different significantly. The microscopic stomach tissue of rats after 4 days (without treatment) is shown in Fig. 12. It shows there is still erosion of all rats mucosa.

Treatment with cimetidine suspension

Two days: Groups of rats given cimetidine suspension show the gastric mucosa in Fig. 13. It shows that there are still many lesions in stomach.

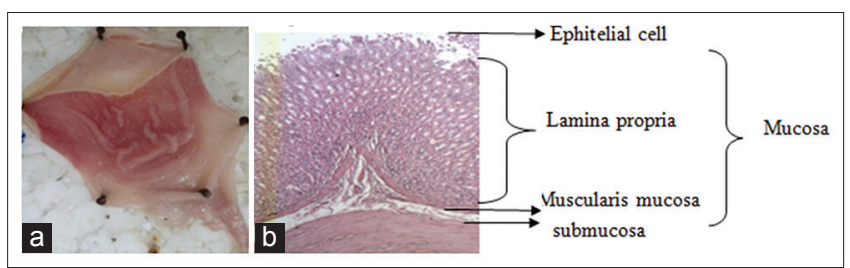

Fig. 6: (a-c) Normal stomach of rat. (a) Macroscopic of gastric mucosa, (b) microscopic of gastric mucosa

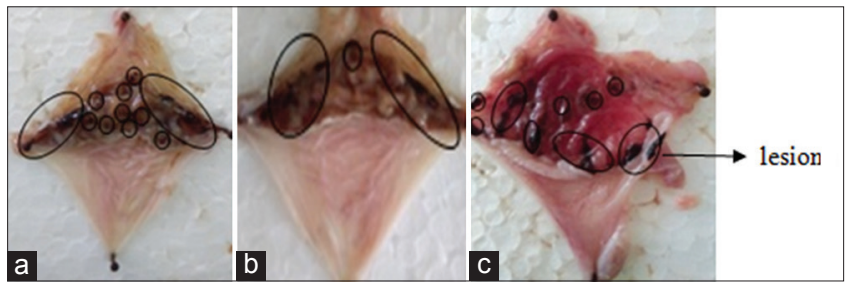

Fig. 7: (a-c) Macroscopic of rats gastric mucosa after induction with $\mathrm{HCl} 0.6 \mathrm{~N}$ solution

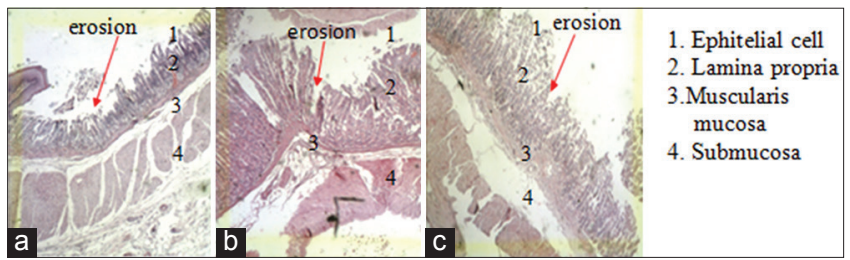

Fig. 8: (a-c) Microscopic of rats gastric mucosa after induction with $\mathrm{HCl} 0.6 \mathrm{~N}$ solution

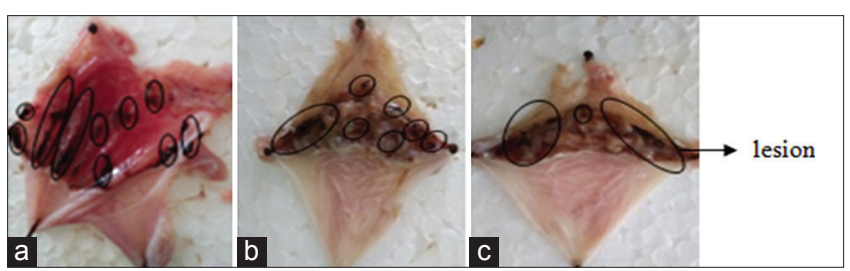

Fig. 9: (a-c) Macroscopic of rats gastric mucosa after 2 days (without treatment) 
After 2 days, the lesion index was $0.12 \pm 0.10$ and the number of lesion was $2.5 \pm 1.76$. If we compared with initial condition, after 2 days, the lesion index and number of lesion are reduced but it is not different significantly. Fig. 14 shows the microscopic gastric mucosa of rats after 2 days. It shows many erosions in the stomach of all rats.

Four days: Fig. 15 shows the gastric mucosa of rats after 4 days for cimetidine suspension. It shows that there are still many of lesions of stomach. After 4 days, the lesion index is $0.036 \pm 0.024$ and the number of lesion is $2.4 \pm 1.14$. If we compared with the condition at 2 days, after 4 days, the lesion index and number of lesion are also decreased, but statistically, it is not different significantly. The microscopic stomach tissue of rats after 4 days (cimetidine suspension) is shown in Fig. 16. It shows there is still erosion of all rats mucosa.

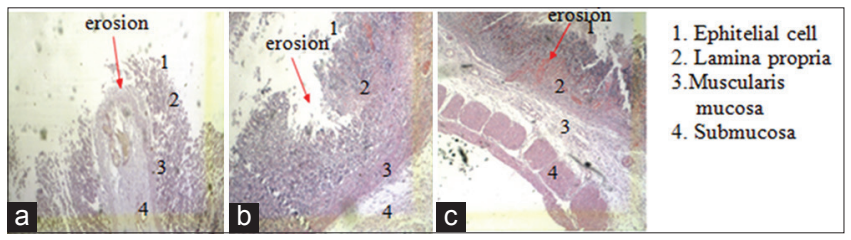

Fig. 10: (a-c) Microscopic of rats gastric mucosa after 2 days (without treatment)

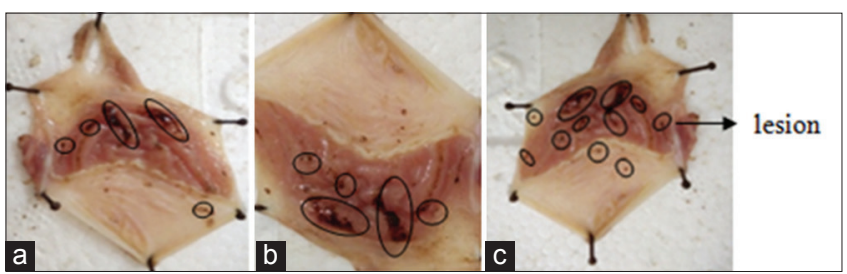

Fig. 11: (a-c) Macroscopic of rats gastric mucosa after days (without treatment)

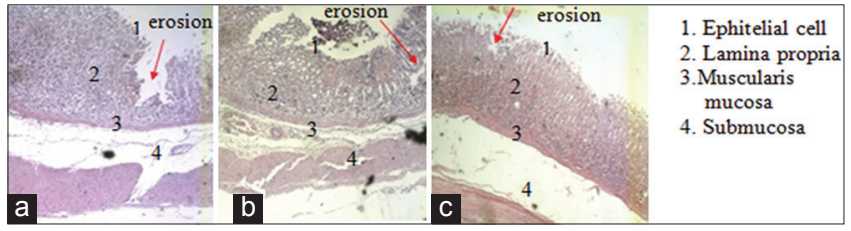

Fig. 12: (a-c) Microscopic of rats gastric mucosa after 4 days (without treatment)

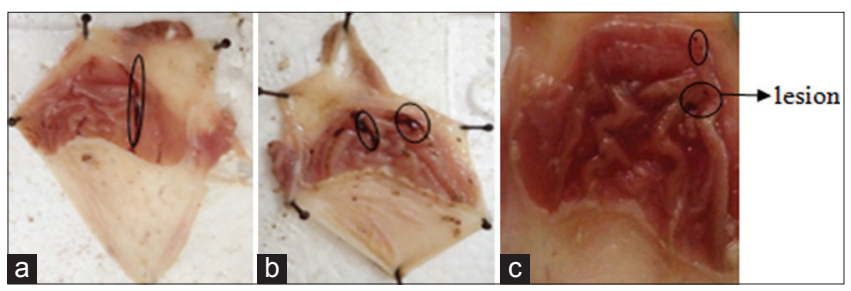

Fig. 13: (a-c) Macroscopic of rats gastric mucosa after 2 days treatment with cimetidine suspension

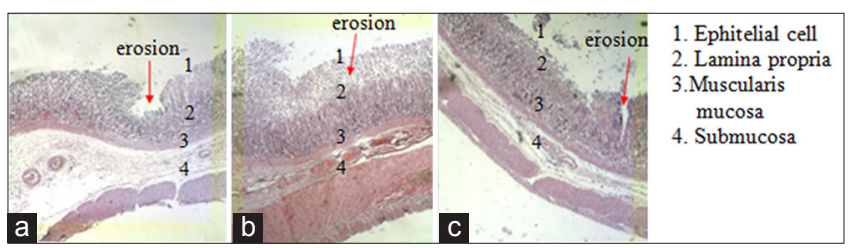

Fig. 14: (a-c) Microscopic of rats gastric mucosa after 2 days treatment with cimetidine suspension
Treatment with hard alginate capsule containing cimetidine

Two days: Groups of rats given hard alginate capsules show the gastric mucosa in Fig. 17. It shows that there are still lesions of the stomach in 1 of 6 rats. After 2 days, the lesion index was $0.007 \pm 0.01$ and the number of lesion was $1.16 \pm 1.60$. If we compared with initial condition, after 2 days, the lesion index and number of lesion are reduced and it is different significantly. Fig. 18 shows the microscopic of gastric mucosa of rats after 2 days. It shows there is still erosion in the stomach in 1 of 6 rats.

Four days: Groups of rats given hard alginate capsules show the gastric mucosa in Fig. 19. It shows no lesion in the stomach. After 4 days, the lesion index was $0.00 \pm 0.00$ and the number of lesion was $0.00 \pm 0.00$. If we compared with 2 days treatment, after 4 days, the lesion index and number of lesion are reduced and it is not different significantly. Fig. 20 shows the microscopic of gastric mucosa of rats after 4 days. It shows that there is no erosion like normal gastric mucosa.

\section{CONCLUSION}

The most suitable alginate capsules formulation for the floating preparation of gastric cimetidine is hard alginate capsules made from sodium alginate 500-600 cP. The release of cimetidine from hard alginate capsules as a floating dosage form is a sustained release.

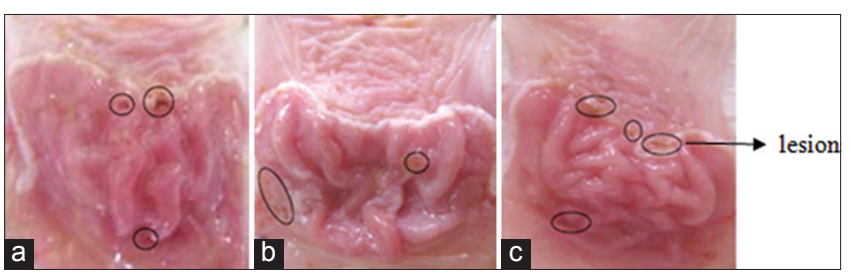

Fig. 15: (a-c) Macroscopic of rats gastric mucosa after 4 days treatment with cimetidine suspension

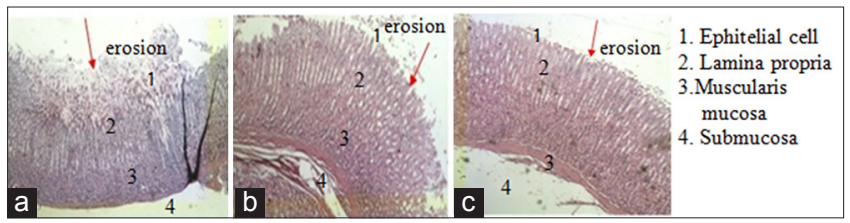

Fig. 16: (a-c) Microscopic of rats gastric mucosa after 4 days treatment with cimetidine suspension

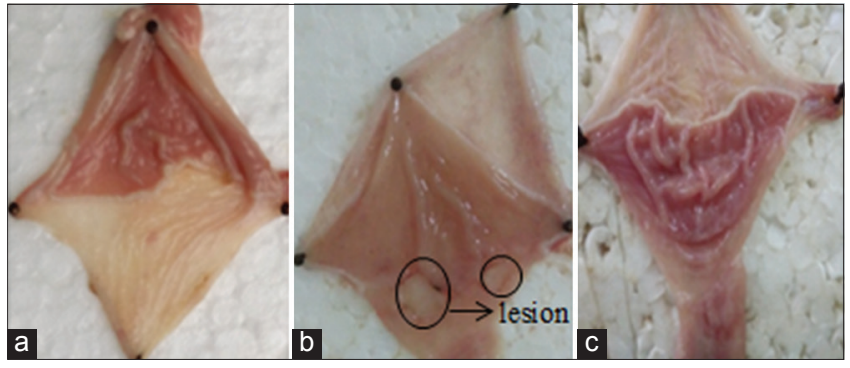

Fig. 17: (a-c) Macroscopic of rats gastric mucosa after 2 days treatment with hard alginate capsules containing cimetidine

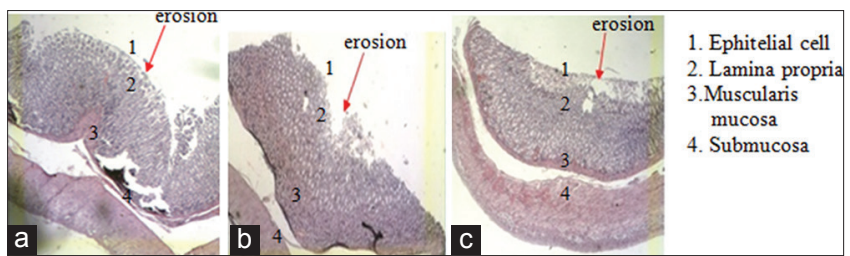

Fig. 18: (a-c) Microscopic of rats gastric mucosa after 2 days treatment with hard alginate capsules containing cimetidine 
Table 2: Cimetidine release from hard alginate capsules that prepared from various viscosity of sodium alginate in artificial gastric fluid pH 1.2

\begin{tabular}{llllll}
\hline Administration interval & Time (h) & \multicolumn{2}{l}{ Amount released (\%) } & \multicolumn{2}{c}{ General requirements of SR[26] (\%) } \\
\cline { 2 - 5 } & & $\mathbf{8 0 - 1 2 0 ~ c P}$ & $\mathbf{3 0 0 - 4 0 0 ~ c P ~}$ & $\mathbf{5 0 0 - 6 0 0 ~ c P ~}$ \\
\hline 0.25 D & $3 \mathrm{~h}$ & 83.03 & 83.23 & 49.80 & $20-50$ \\
0.5 D & $6 \mathrm{~h}$ & 91.89 & 86.64 & 61.31 & $45-75$ \\
1 D & $12 \mathrm{~h}$ & 96.27 & 86.69 & 80.03 & $\geq 75$ \\
\hline
\end{tabular}

D: Dose interval $(12 \mathrm{~h})$

Table 3: Average lesion index and the number of lesion in each group $(n=6)$ during the treatment

\begin{tabular}{|c|c|c|c|c|c|c|}
\hline \multirow[t]{2}{*}{ Days } & \multicolumn{3}{|c|}{ Lesion index $(n=6)(X \pm S D)$} & \multicolumn{3}{|c|}{ Number of gastric lesion $(n=6)(X \pm S D)$} \\
\hline & $\begin{array}{l}\text { Distilled water } \\
\text { (without treatment) }\end{array}$ & $\begin{array}{l}\text { Treatment with } \\
\text { cimetidine } \\
\text { suspension }\end{array}$ & $\begin{array}{l}\text { Treatment with hard } \\
\text { alginate capsules } \\
\text { containing cimetidine }\end{array}$ & $\begin{array}{l}\text { Distilled water } \\
\text { (without treatment) }\end{array}$ & $\begin{array}{l}\text { Treatment with } \\
\text { cimetidine } \\
\text { suspension }\end{array}$ & $\begin{array}{l}\text { Treatment with } \\
\text { hard alginate } \\
\text { capsules containing } \\
\text { cimetidine }\end{array}$ \\
\hline 0 & $0.44 \pm 0.08$ & $0.44 \pm 0.08$ & $0.44 \pm 0.08$ & $8.16 \pm 2.22$ & $8.16 \pm 2.22$ & $8.16 \pm 2.22$ \\
\hline 2 & $0.18 \pm 0.16$ & $0.12 \pm 0.10$ & $0.007 \pm 0.01$ & $5.8 \pm 2.92$ & $2.5 \pm 1.76$ & $1.16 \pm 1.60$ \\
\hline
\end{tabular}

SD: Standard deviation

Table 4: Pharmacokinetics parameter of cimetidine using hard gelatin capsules and hard alginate capsules after oral administration in rabbits $(n=6)$

\begin{tabular}{llll}
\hline Samples & Cmax $(\boldsymbol{\mu g} / \mathbf{m l})$ & Tmax $(\min )$ & AUC $^{\mathbf{0} \infty}(\mathbf{m i n} \cdot \boldsymbol{\mu g} / \mathbf{m l})$ \\
\hline $\begin{array}{l}\text { Hard gelatin } \\
\text { capsules }\end{array}$ & $4.429 \pm 1.512$ & $15 \pm 14.747$ & $2290.315 \pm 475.162$ \\
$\begin{array}{l}\text { Hard } \\
\text { alginate }\end{array}$ & $6.674 \pm 2.629$ & $180 \pm 70.142$ & $3141.055 \pm 835.113$ \\
capsules & & & \\
\hline
\end{tabular}

AUC: Area under the curve

The hard alginate capsules which contain cimetidine have higher bioavailability than cimetidine in hard gelatin capsules. The hard alginate capsules containing cimetidine are more effective as antiulcer effect compared to cimetidine given in suspension form.

\section{ACKNOWLEDGMENT}

This work was supported by University of Sumatera Utara through the TALENTA Research, scheme of Penelitian Unggulan Universitas (University Excellent Research) 2017.

\section{AUTHOR'S CONTRIBUTIONS}

Ririyen Dessy N Siahaan conducted the study, Hakim Bangun planned and designed the study, and Sumaiyah supported the conduction of study.

\section{CONFLICT OF INTEREST}

The authors declare that they have no conflict of interest.

\section{REFERENCES}

1. Corwin EJ. Handbook of Pathophysiology. $3^{\text {rd }}$ ed. Philadelphia, PA: Pennsylvania State University, University Park; 2008. p. 603.

2. Dhiman S, Singh TG, Rehni AK, Sood S, Arora S. Gastroretentive: A controlled release drug delivery system. Asian J Pharm Clin Res 2011;4:5-13

3. Shasank C, Prabha K, Sunil S, Kumar AV. Approaches to increase the gastric residence time: Floating drug delivery systems-a review. Asian J Pharm Clin Res 2013;6:1-9.

4. Vinod M, Jitendra N, Priyenka S, Navin S. Formulation and in vitro evaluation of cimetidine microsphere as gastro retentive floating drug delivery system. Int J Chem Environ Biol Sci 2013;1:701-6.

5. Srivastava AK, Ridhurkar DN, Wadhwa S. Floating microspheres of cimetidine: Formulation, characterization and in vitro evaluation. Acta

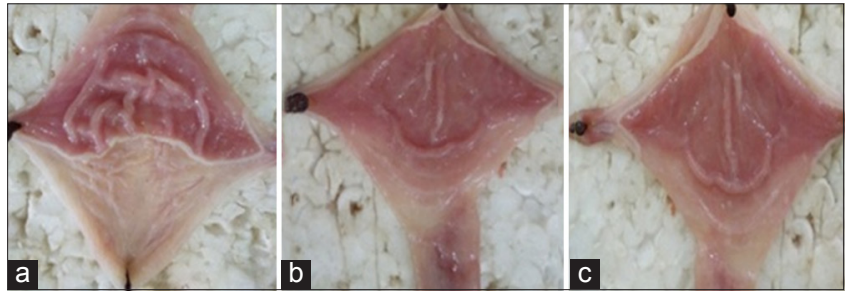

Fig. 19: (a-c) Macroscopic of rats gastric mucosa after 4 days treatment with hard alginate capsules containing cimetidine

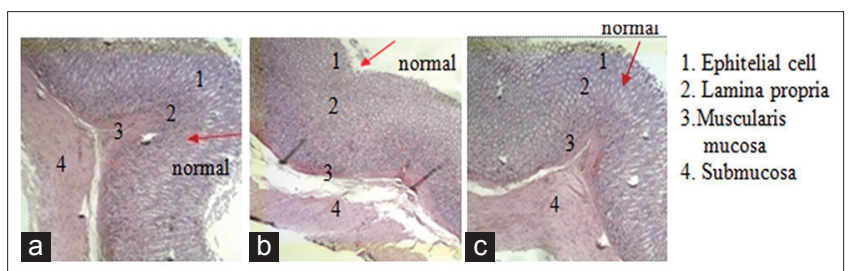

Fig. 20: (a-c) Microscopic of rats gastric mucosa after 4 days treatment with hard alginate capsules containing cimetidine

Pharm 2005;55:277-85.

6. Begum A, Raju B. In vitro and in vivo evaluation of cimetidine loaded mucoadhesive microspheres. Int J Drug Deliv 2016;8:60-5.

7. Nasa P, Mahant S, Sharma D. Floating systems: A novel approach towards gastroretentive drug delivery systems. Int J Pharm Pharm Sci 2010;2:2-7.

8. Balata G. Design and evaluation of gastroretentive floating tablet of nizatidine: A trial to improve its efficacy. Int J Pharm Pharm Sci 2014;6:423-9.

9. Marabathuni VJ, Deveswaran R, Bharath S, Basavaraj BV, Madhavan V. Design and optimization of multiparticulate gastroretentive delivery system of ranitidine hydrochloride. Int J Pharm Pharm Sci 2012;4:597-603.

10. Hasan MJ, Kamal BA. Formulation and evaluation of ranitidine hydrochlorideas floating in situ gel. Int $\mathrm{J}$ Pharm Pharm Sci 2014;6:401- 5 .

11. Draget KI, Smidsrod O, Gudmund S. Alginate from Algae. Weinheim: Wiley Vch Verlag GmbH and Co; 2005.

12. Aryana, Sinurat D, Ervina I, Bangun H. Formulation of alginate based metronidazole periodontal gel. Asian J Pharm Clin Res 2014;7:224-7.

13. Mariadi, Bangun H, Karsono. Formulation and in vitro evaluation of gastroretentive drug delivery system of antacids using alginate-chitosan films. Int J Pharmtech Res 2015;8:1-12.

14. Adliani N, Bangun H, Karsono. Preparation and evaluation of floating- 
mucoadhesive alginate beads as gastroretentive drug delivery system of antacids. Int J Pharmtech Res 2016;9:212-22.

15. Arianto A, Bangun H, Harahap U, Ilyas S. The comparison of swelling, mucoadhesive, and release of ranitidine from spherical matrices of alginate, chitosan, alginate-chitosan, and calcium alginate-chitosan. J Pharmtech Res 2014;6:2054-63.

16. Arianto A, Bangun $\mathrm{H}$, Harahap U, Ilyas S. Effect of alginate chitosan ratio on the swelling, mucoadhesive, and release of ranitidine from spherical matrices of alginate-chitosan. J Pharmtech Res 2015;8:653- 65 .

17. Kametani F, Bangun H, Ikeda Y, Shimabayashi S. Interaction of alginic acid with organic diacidic piperazine. Chem Pharm Bull 1990;38:2623- 6 .

18. Bangun H, Simanjuntak MT, Tarigan P, Ismanelly T. Preparation and characterization of gastric resistant alginate capsules. Media Farm 2005;13:70-9.

19. Arianto A, Bangun H, Yohana A, Silalahi J. Floating gastroretentive of amoxicillin using hard alginate capsules and its antibacterial activities. Asian J Pharm Clin Res 2017;10:413-9.

20. Katzung BG. Basic and Clinical Pharmacology. United States of America: McGrawHill Companies Inc; 2007. p. 1013-5.

21. Shargel L, Yu A. Applied Biopharmaceutics and Pharmacokinetics. $5^{\text {th }}$ ed. Boston: McGraw Hill; 1999. p. 253, 263

22. Mastiholimath VS, Dandagi PM, Gadad AP, Mathews R, Kulkarni AR.
In vitro and in vivo evaluation of ranitidine hydrochloride ethyl cellulose floating microparticles. J Microencapsul 2008;25:307-14.

23. Arianto A. Antiulcer effect of gastroretentive spherical matrices of alginate-chitosan containing ranitidine $\mathrm{HCl}$. Int $\mathrm{J}$ Pharmtech Res 2016;9:342-52.

24. Saritha D, Satish D, Rao M. Formulation and evaluation of gastroretentive floating tablets of domperidone maleate. J Appl Pharm Sci 2012;2:68-73.

25. Sabiu S, Garuba T, Sunmonu T, Ajani E, Sulyman A, Nurain I, et al. Indomethacin-induced gastric ulceration in rats: Protectiveroles of spondiasmombin and ficus exasperate saheed. Toxicol Reports 2015;2:261-7.

26. Arianto A, Bangun $\mathrm{H}$. Healing effect of alginate liquid against $\mathrm{HCl}-$ induced gastric mucosallesion in rats. Int J Pharmtech 2016;9:287-96.

27. Bangun H. Preparation, Physical Properties, and Application of Hard Alginate Capsules. Proceeding of International Seminar on Individualized Pharmaceutics for Optimized Drug Delivery, College of Pharmacy, Seoul National University; 2012.

28. Murthy KS, Ghebre-Sellassie I. Current perspectives on the dissolution stability of solid oral dosage forms. J Pharm Sci 1993;82:113-26.

29. Eroschenko VP. Difiore's Atlas of Histology with Functional Correlation. $12^{\text {th }}$ ed. USA: Lippincolts Williams \& Wilkins/Wolter Kluwer Health Inc; 2013. p. 324-31. 